\title{
Forging the American Century: World War II and the Transformation of U.S. Internationalism
}

Jorrit van den Berk and Frank Mehring

HCM 7: 1038-1048

DOI: $10.18352 / \mathrm{hcm} .597$

\begin{abstract}
This essay introduces the special issue on the forging of the "American Century', which brings together American and European scholars to revisit the time between the entrance of the U.S. into World War II and the era of the European Reconstruction. Exploring the multivalent agents and forces involved in forging the American Century, the various articles bring into play national and transnational trajectories that inform politics, media and popular culture. Rather than adhering to a single theoretical approach, the articles offer a wide range of intercultural, theoretical and methodological perspectives.
\end{abstract}

Keywords: American Century, Americanization, cultural diplomacy, public diplomacy, soft power, transatlantic transfer, World War II

\section{The American Century}

In the aftermath of the election of President Donald Trump, the American Century is front-page news yet again. President Trump's problematic invocation of 'America First', which seems to hark back, though probably unintentionally, to the isolationist America First Committee that opposed U.S. intervention in World War II; his threats to withdraw the country from international partnerships and treaties, a threat that was not realized in the case of NATO and NAFTA, but did lead to the U.S.'s withdrawal from the Transpacific Partnership and the 
Paris climate agreement; and Trump's very controversial statements on immigration, have inspired journalists and political commentators in the U.S., Canada and Europe to return to Henry Luce's original idea of an American Century.

While Luce's famous I94I article may strike the modern reader as a confusing mix of jingoism, democratic idealism, free market enthusiasm, nationalism and naiveté, his wariness of isolationism and insistence that the United States should be a great moral beacon to the world has appeared to some as particularly relevant in the Trump era. In an article for The Atlantic, for example, Richard Stengel (who, as a former editor of Time Magazine, defines himself as a direct successor of Luce's) claims that 'Trump's administration is the death knell of the American Century'. This is so because, according to Stengel, U.S. power and influence are based on America's willingness to serve as a global model and a guarantor of the rule of law, or, in other words, 'we were the one nation that did not always put ourselves first' ${ }^{\mathrm{I}}$ In somewhat similar terms, the editors of the Canadian Globe and Mail remember America's determination to rebuild Germany and Japan after World War II as 'one of history's greatest acts of enlightened self-interest ... America was the free world's leader because it did more than just put America First'. ${ }^{2}$ Adam Tooze, of the German Die Zeit, notes that while Trump seems to consider 'America First' as a liberation - now America can jettison its obligations and be like the others - the whole point was always to not be like the others, to perform an exceptional role: 'This is the sense in which the American Century has ended. And this is what the world now has to deal with: a dominant superpower, still by far the most dominant that history has ever recorded, but shorn of aspiration to moral leadership' ${ }^{3}$

We should be careful not to be swept along in this stream of eulogies for the American Century. It is not, after all, the first time that its end has been announced. In fact, the question of whether America has entered a final phase of decline seems to re-emerge at least once every generation. ${ }^{4}$ Perhaps it is not altogether surprising, then, that the concerns so recently voiced by journalists and commentators have also affected scholarship. Historian David Schmitz, for example, suggested that the internal divisions and economic decline that followed Nixon's handling of the Vietnam War signified the end of the American Century. ${ }^{5}$ Alternatively, Samuel Huntington predicted a crisis of national identity 
caused by the 'Latin-Americanization' of the United States and the multicultural turn. As long as Americans cannot answer the question 'who are we' with a proud acceptance of traditional core cultural values rooted in Anglo-Protestant culture and its political Creed of liberty and democracy, there could be no convincing agenda for a powerful foreign policy. Huntington outlined a potentially disastrous development towards a 'racially intolerant country with high levels of intergroup conflicts' ${ }^{6}$ Finally, military adventurism in Iraq and economic decline, especially the collapse of the U.S. financial system in 2007, were seen by a number of scholars and commentators as the culmination of a process that marked the end of the American Century. ${ }^{7}$

Others have been less pessimistic, both about the nature of the American Century and its future. Joseph Nye concludes that if the American Century is defined as 'the extraordinary period of American pre-eminence in military, economic, and soft power resources', its end is not in sight. ${ }^{8}$ It is exactly the matter of soft power, or the ability of the United States to forge and to project attractive models, that has become the centre of recent scholarship - an international and transnational discourse to which this volume contributes. Despite her critical observation regarding the shift of cultural exports from jazz to classic Hollywood films during the Cold War to a deplorable mix of 'raunchy sex comedies, blood-drenched horror films, and crude talk and reality shows into non-Western societies', media theoretician Martha Bayles offers a number of future-oriented suggestions for public diplomacy to rethink the use of popular culture as a means to recalibrate the lens of perception outside of the U.S. and recognize the promise of American democracy. ${ }^{9}$ The Dutch scholar Rob Kroes sounds pessimistic when he argues that transnationalism, understood as the academic antidote to American exceptionalism, might not be a concept to reflect the realities of American politics any longer. He suggests that 'it might be a while before the United States finds a president as open-minded as cosmopolitan, as the one who has just completed two full terms in the White House'. Nevertheless, Kroes implies that the U.S. does have the power and potential to return to the status of a global reference culture it held over the past 70 years. ${ }^{10}$

While our aim here is not to engage in the discussion about the future of American power, there is an important point to take away from these arguments: the American Century, when conceived in terms of the 
United States being a model or a beacon, exactly the terms that have most often been evoked since the election of Trump, is bigger than a single president. As David Ellwood argues in his article in this special issue:

Luce anticipated an era when governments and others would choose soft power methods from the conviction that their nations, institutions, values, personalities are endowed with a charisma of their own which can be deployed to generate prestige, attention and respect in the world. Call it 'the force of example', a way for countries to promote their formulas of life which is persuasive, not coercive, attractive and not manipulative, consensual and not brutal.

'Forging the American Century' seeks to combine the current concern for America's changing role in the world with new and developing insights into the nature of international relations to revisit the origins of the American Century: World War II and its aftermath. This issue is not about the high diplomacy of the war, nor is it necessarily about the start of the Cold War. Instead, it addresses the ways in which the World War and America's rise to global power drove Americans in different fields, both inside and outside the sphere of formal diplomacy, to forge new connections with the world. The articles also address the many ways in which people around the world responded to the new or changing American presence.

Our overall purpose is to show that the foundations of American internationalism, in this defining moment of America's rise to global pre-eminence, were never solely about government policies. During World War II and its aftermath, numerous actors from different fields came together to create a new understanding of America's role in the world. The result was a global presence that was complex, but also highly dynamic. U.S. governments deployed soft power strategies to present the outlines of a new world order, but at the same time, American moviemakers, soldiers' wives, writers and artists served as the vanguards of America in Europe. They strengthened old connections and made new ones while reshaping both their compatriots' and European understandings of what it meant to live in the American Century. This issue contributes to the ongoing discourse on the forging of the 'American Century', bringing together American and European 
scholars to revisit the time between the entrance of the U.S. into World War II and the era of the European Reconstruction. The articles conjointly explore the multivalent agents and forces involved in forging of the American Century. They bring into play national and transnational trajectories that inform politics, media and popular culture. Rather than adhering to a single theoretical approach, they offer a wide range of diverse intercultural perspectives and are informed by a wide array of theoretical and methodological approaches.

\section{World War II and U.S. Internationalism}

Three articles deal directly with the question of how U.S. internationalism, the purposes and goals of its international engagement, was shaped by and during World War II. In his essay on 'The Force of American Modernity', David Ellwood argues that America remains the sole 'soft power' superpower. The reason is simple: no nation like the U.S. has produced examples of innovation across so many technological and cultural sectors which the others must respond to if they wished to be considered modern and not marginal. The story begins in World War II, when the U.S., led by its government, consciously decided to project its ideas and examples of the links between consumerist prosperity and political stability under liberal capitalism. But this dynamic force for change, Ellwood claims, has always produced reaction, adaptation, even rejection, and nowhere more so than in Europe. From Hollywood to McDonald's, from Fordism to Uber, Europe has always been the place where the American 'soft power' challenge in all its forms was most hotly felt and debated. History shows, however, that this form of the politics of modernization has always divided the Europeans, and responses to the proposed TTIP once more confirm the old patterns.

Giles Scott-Smith puts his academic searchlight on what he describes as 'competing internationalisms' in the foundation of the United Nations Information Office. The UNIO, dating from I942, holds the distinction of being both the first international agency of the embryonic U.N. network and the first to hold the United Nations label. Run from I 942 to I 945 from two offices in New York and London, these two were merged at the end of World War II to form the U.N. Information Organisation, and subsequently transformed into the Department of 
Public Information run from U.N. headquarters in New York. ScottSmith's article provides a perspective on the formation of the UNIO from the viewpoint of the differing power relations and worldviews between the United States and Britain during the war. The UNIO story therefore adds an extra dimension to how Britain attempted to energize American internationalism in the cause of the anti-Nazi war effort, with the ultimate goal of bringing the United States to commit to the Allied cause. Once the United States did enter the war, it gradually took control of the wartime information campaign under the name of the United Nations, in so doing transforming the British-founded apparatus into a network for promoting U.N. organization and ideals.

At the same time, segregationist politicians from the U.S. South played key roles in devising plans for the reconstruction of Germany, the Marshall Plan and the drafting of displaced persons legislation. In 'Jim Crow Democracy', Maarten Zwiers discusses how Jim Crow ideology calibrated the global and domestic order that emerged from the ashes of World War II. Southern conservatives dealt with national and foreign issues from a regional perspective, which was based on the protection of agricultural interests and a nascent military-industrial complex, but above all, on the defence of white supremacy. In general, southern politicians followed a lenient course toward Germany after the country's defeat in World War II, for various reasons. The shared experience of post-war reconstruction, containment of communism and feelings of kinship between the Germanic people and the Anglo-Saxons of the U.S. South were some of the reasons why white southerners did not endorse punitive measures against the former enemy. For white southerners, Zwiers argues, an obvious connection existed between the local and the global, which strongly reverberated in the formation of U.S. foreign and domestic policy in the post-war world. The rebuilding of Germany and the fugitive question were shaped on the basis of a Jim Crow blueprint.

\section{The U.S. Military and Soft Power}

Two articles suggest how the U.S. military presence in Europe should be understood as a form of U.S. soft power or alternative diplomacy, while they also explain how the military presence was both welcomed 
and contested in European societies. In his article 'Embodying the American Century', Dario Fazzi asks whether U.S. military bases are outposts of empire or ultimate beacons of freedom. Scholars have interpreted the American global web of military bases both ways. In Europe, in particular, U.S. military deployment has been quite exceptional: since the end of World War II, American bases have mushroomed and grown steadily all over the continent. Originally meant to keep Western Europe from totalitarianism, embed it in a system of collective, transatlantic security, and tie it firmly to the free market and capitalism, U.S. bases in Europe eventually projected and embodied the American Century. This article focuses on the case of an American base in the Dutch village of Schinnen to show that American military outposts in Europe have constantly disseminated the American way of life in a number of ways: they have affected the local economy, generated cross-cultural encounters and deeply impacted the surrounding environment. While taking into account both the positive and negative dynamics set into motion by the American military presence in Schinnen, this article invites further inquiry into the relationship between the centre of the American empire and its periphery, and it simultaneously puts at test the historical and historiographical viability of the American Century.

François Doppler-Speranza examines the role of women in public diplomacy operations on and around U.S. military bases in France, especially during the Cold War. Based on original and unpublished archives, his article 'Trading Boots for Dancing Shoes' illustrates the diplomatic role of military officers' wives in France and shows the vested interest of the military establishment in cooperating with civilian offices of public diplomacy. Indeed, the more the United States demonstrated its leadership on the global scene, manifested by a wave of unprecedented military incursions into foreign territories in the twentieth century, the more the tight government control gave way to a strategy focusing on informal contacts between women of both countries at the local level. Doppler-Speranza argues that military wives, often considered a traditional cultural vehicle, contributed to the 'parabellicist' approach of U.S. public diplomacy strategy which, as military intelligence theorist Walter C. Sweeney and French writer Jacques Ayencourt suggested, aimed to generate 'a nation in arms'. Thus, Doppler-Speranza contends that women's social and cultural initiatives intended not to influence French women by pushing American values, but to support the U.S. 
national security effort from a bottom-up perspective, which was the most critical challenge behind the expression of the 'American Century' in France.

\section{Diplomacy of Art, Literature and Popular Culture}

Finally, three articles investigate the role of art, writers and popular culture to function as informal diplomats, translating the world to America, and America to the world. First, Frank Mehring turns to the complex function of art as a potential, sometimes neglected means of democratic persuasion. In 'Advancing American Art and Intercultural Confrontations in Germany, I945-I948', Mehring critically addresses the multivalent function of American art exhibitions in the period of deNazification and re-democratization asking: What kind of cultural and political parameters shaped the perception of American Art in Germany during the early post-war years? The article investigates intercultural confrontations surrounding travelling exhibitions of American art and the critical response of German audiences in the first years after World War II. It focuses on intercultural confrontations by first looking at the concept of travelling exhibitions such as Advancing American Art from I947, the critical response and the reasons for its failure. In a second step, Mehring analyzes the role of transatlantic cultural mediators to understand developments in the European perspective on American art. As an example, his article turns to the German-born artist Hilla von Rebay, who emigrated in 1927 to the United States and organized the German tour of Zeitgenössische Kunst und Kunstpflege in U.S.A. (Contemporary Art and the Promotion of Arts in the U.S.A.) authorized by the Office of Military Government, United States (OMGUS) in I948. Mehring concludes that the project of 'advancing American art' resembles a struggle with many setbacks due to lack of official support and problems of finding a larger public in the early years after World War II.

Secondly, Hans Bak's article, 'For the Nation and the World', examines the extent to which the efforts of critic Malcolm Cowley (I898I989), both in writing the concluding chapter on 'American Books Abroad' for the influential Literary History of the United States (I948) and, as guest editor, for James Laughlin's Ford Foundation magazine 
Perspectives USA, dovetailed with the aims of U.S. cultural diplomacy and (wittingly or unwittingly) played its part in what Frances Saunders has called the 'cultural cold war'. He concludes in part that Cowley's writing for Perspectives USA

served, implicitly if not overtly, as advertisements for the American way of life that could help to win the hearts and minds of Europeans. The conspicuous absence of politics and any references to the Cold War anxieties on the domestic front experienced by Cowley himself also fit into Laughlin's policy - the absence of politics in itself served a political purpose.

Considering recent developments regarding populism in the transatlantic sphere, the final contribution critically engages with the fear of 'Fascism coming to America' as a postscript to the preceding essays on the function of the U.S. as a reference culture. For almost a century, American politicians and social commentators, followed by novelists, Hollywood movie makers and television producers have agonized about the menace of fascism, and its ability to corrupt the United States' constitutional republic, supposedly moderate, strong and firm. Bruce Kuklick calls attention to four facets of this huge set of issues: the creation of the understanding of fascism in I939-I94I; the connection between political crisis and popular culture renderings of it; the contribution of European scholars to the conventional conceptual framework; and an exploration of the penchant of American scholars for the notion.

\section{Notes}

I Richard Stengel, 'The End of the American Century', The Atlantic (26 January 20I7); https://www.theatlantic.com/politics/archive/20I7/oI/endof-the-american-century/5I4526/ (accessed I9-09-2019).

2 'How Trump's “America First” will end the American Century', The Globe and Mail (2 I January 20I7); https://www.theglobeandmail.com/opinion/ editorials/how-trumps-america-first-will-end-the-american-century/ article336939I3/ (accessed I9-09-2019).

3 Adam Tooze, 'Goodbye to the American Century', Zeit Online (I 3 January 20I7); http://www.zeit.de/politik/ausland/20I7-or/usa-hegemony-donaldtrump-rise-leadership-europe (accessed I9-09-2019). 
4 For a brief discussion of this trend: Joseph Nye, Is the American Century Over? (Cambridge, Malden, 20 I5) 22-6.

5 David F. Schmitz, Richard Nixon and the Vietnam War: The End of the American Century (Lanham, 2014), especially I09-Io.

6 Samuel P. Huntington, Who Are We? The Challenges to America's National Identity (New York etc, 20I4) 20.

7 See for example Andrew J. Bacevich (ed.), The Short American Century. A Postmortem (Cambridge, 20I2) and David Mason, The End of the American Century (Lanham, 2009).

8 Nye, The American Century, 88.

9 Martha Bayles, Through a Screen Darkly. Popular Culture, Public Diplomacy, and America's Image Abroad (New Haven, London, 20 I5) 8.

Io Rob Kroes, 'Exceptionalism, Mental Intertexts, and Transnationalism', William E. Leuchtenburg (ed.), American Mosaic (Amsterdam, 2017) I 22.

\section{About the Authors}

Jorrit van den Berk is an assistant professor of North American Studies at Radboud University, Nijmegen, the Netherlands, where he teaches U.S. history, politics and foreign relations. His research involves U.S. diplomacy of the World War II era. His work on U.S.-Central American relations during the I930s and I940s includes the book Becoming a Good Neighbor among Dictators (Palgrave, 20I8). His current research interests include transatlantic relations and public diplomacy. E-mail: j.vandenberk@let.ru.nl

Frank Mehring is professor of American Studies at Radboud University, Nijmegen, the Netherlands. His research focuses on cultural transfer, immigration, music and intermediality. In 20I2, he received the biennial Rob Kroes Award for his monograph The Democratic Gap: Transcultural Confrontations of German Immigrants and the Promise of American Democracy (20I4). Other publications include Sphere Melodies on American avant-garde music (2003), a biography on Karl/ Charles Follen (2004), Transcultural Spaces: Challenges of Urbanity, Ecology, and Environment (2010), and The Soundtrack of Liberation (20I5). Mehring is a board member of the European Association of American Studies and the Netherlands American Studies Association, 
the International Committee of the American Studies Association and part of the steering committee of the European Digital Studies Network. He co-curated exhibitions on the artist Winold Reiss, the Marshall Plan and Liberation Songs in New York, Nijmegen and The Hague. E-mail: f.mehring@let.ru.nl 